\title{
Purwarupa Jaringan Sensor Medis Nirkabel Berbasis Komputasi Awan
}

\author{
David Puiterson dan Wirawan \\ Departemen Teknik Elektro, Fakultas Teknologi Elektro, Institut Teknologi Sepuluh Nopember (ITS) \\ E-mail: wirawan@ee.its.ac.id
}

\begin{abstract}
Abstrak-Teknologi Wireless Sensor Network (WSN) merupakan bidang ilmu telekomunikasi yang mengembangkan suatu jaringan yang terdiri dari sensor terdistribusi dan terhubung secara nirkabel. Penelitian ini mengimplementasikan jaringan sensor nirkabel pada bidang medis dengan tujuan mempermudah proses monitoring kondisi tubuh pada lokasi berbeda antara node sensor dan pihak yang melakukan monitoring. Parameter yang diukur sensor terdiri dari detak jantung dan suhu badan. Jaringan sensor terhubung secara nirkabel dengan protokol 802.11 (wifi) yang dirutekan oleh gateway berupa router yang tersambung dengan internet. Data sensor akan dikirim menuju server awan dengan memanfaatkan teknologi Cloud Computing, yaitu teknologi dimana pusat jaringan dan sistem penyimpanan berada pada lokasi berbeda (remote) dari jaringan sensor. Purwarupa penelitian ini terdiri dari NodeMCU sebagai mikrokontroler, sensor detak jantung SEN11574 dan sensor suhu badan DS18B20, ESP8266 sebagai modul wifi, router AC750 dan jaringan ubidots sebagai penyedia layanan jaringan awan yang menghasilkan sebuah jaringan sensor medis nirkabel berbasis komputasi awan yang dapat memonitoring dan menyimpan data medis apabila terhubung dengan internet.
\end{abstract}

Kata Kunci-Wireless Sensor Network, Medical Sensor, Cloud Computing.

\section{PENDAHULUAN}

$\mathbf{J}_{\mathrm{t} t \mathrm{~s}}$ ARINGAN sensor nirkabel merupakan cabang penelitian telekomunikasi yang mempelajari tentang jaringan sensor yang terdistribusi pada suatu lokasi yang terhubung antara satu sama lain secara nirkabel. Penerapan jaringan sensor nirkabel di Indonesia masih terbatas pada monitoring lalu lintas, perkotaan dan infrastruktur [1]. Studi ini mencoba mengimplementasikannya pada bidang medis, dimana diharapkan sensor akan mempermudah tenaga medis untuk memonitoring kondisi pasien secara jarak jauh.

Salah satu cara penerapan jaringan sensor nirkabel yang populer adalah penggunaan protokol zigbee 802.15. [2] dimana penggunaannya di rumah sakit dan puskesmas di Indonesia hampir tidak digunakan. Studi ini mencoba mengaplikasikan protokol koneksi nirkabel wifi 802.11 yang terdapat sekarang sudah terdapat pada rumah sakit dan beberapa pusat kesehatan masyarakat, sehingga sesuai dengan kondisi praktis tenaga medis di Indonesia.

Kondisi kesehatan pasien yang dapat dimonitor secara berkala adalah detak jantung dan suhu badan, sehingga penulis merancang sebuah purwarupa sensor medis yang terdiri dari kedua parameter tersebut. Purwarupa juga akan didesain sedemikian rupa dengan ukuran yang minimalis dan umur hidup yang panjang. Salah satu tantangan dalam jaringan sensor nirkabel adalah masalah keamanan dan privasi, terutama pada bidang medis mengenai keamanan data dan kondisi pasien [3]. Studi ini mencoba mengatasi permasalahan tersebut dengan menggunakan teknologi komputasi awan, dimana jaringan data dari sensor akan dikirim menuju jaringan awan dimana sistem keamanannya akan terdiri dari sistem enkripsi jasa penyimpana pada server awan.

Melalui purwarupa ini tenaga medis dapat memonitoring kondisi pasien pada lokasi berbeda secara real time dan dapat menyimpan informasi pasien sesuai kebutuhan, dengan sistem keamanan dan penyimpanan yang tersedia pada jaringan awan.

\section{URAIAN PENELITIAN}

\section{A. Jaringan Sensor Nirkabel}

Jaringan sensor nirkabel merupakan suatu jaringan yang terdiri beberapa sensor yang terdistribusi pada lokasi berbeda dan dapat bekerja secara independen dalam memperoleh dan mengirim informasi secara nirkabel. Jaringan tersebut terdiri dari beberapa node yang merupakan sebuah rangkaian yang terdiri dari mikrokontroler, sensor, transceiver, dan power supply yang kemudian terhubung menuju sebuah gateway yang bekerja seperti pintu gerbang dalam memproses informasi yang dikirim oleh sensor menuju komputer pusat. Sebuah jaringan dapat terdiri dari beberapa gateway yang masing-masing terhubung dengan beberapa node.

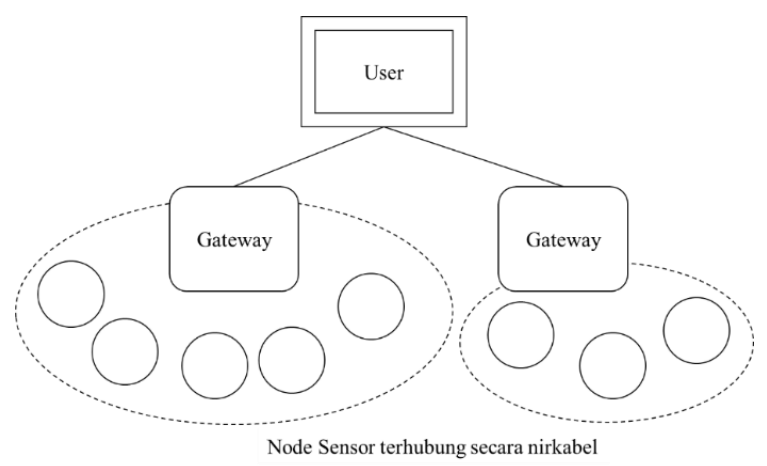

Gambar 1. Topologi jaringan sensor nirkabel

Implementasi jaringan sensor nirkabel dilakukan dengan tujuan mempermudah pengambilan data secara otomatis, pada beberapa lokasi umum sampai pada daerah yang tidak bisa dijangkau oleh manusia dengan ukuran yang kecil dan penggunaan sumber daya yang minimum. Tujuan ini 
menghasilkan beberapa kriteria penting dalam proses perancangan jaringan sensor nirkabel, yaitu [4]:

1. Sumber daya node, dapat berupa baterai atau menggunakan teknik panen energi di lingkungan sekitar seperti panel surya.

2. Desain node, ukuran yang kecil untuk portabilitas, daya tahan yang kuat apabila diletakkan pada lingkungan rawan bencana.

3. Biaya, dengan alasan jumlah node yang banyak, maka desain sebuah node dirancang semurah mungkin untuk menimalisir pengeluaran.

4. Keamanan jaringan, apabila sensor mengambil data yang bersifat rahasia maka keamanan sebuah jaringan dan node harus diperhitungkan dalam rancangan awal.

Implementasi jaringan sensor pada bidang medis secara umum dikenal dengan istilah jaringan sensor area tubuh atau body sensor area network dan diklasifikasikan sesuai cara pemasangan dan parameter yang dimonitor seperti sensor detak jantung, suhu badan, tekanan darah, dan saturasi oksigen. Sensor dapat dipasangkan secara langsung di tubuh pasien atau disuntikkan ke dalam tubuh untuk pemeriksaan yang lebih mendetail di dalam tubuh seperti untuk mendeteksi kualitas saluran darah atau saluran pencernaan [5].

\section{B. Wifi 802.11}

Wifi merupakan teknologi jaringan nirkabel berbasis standar IEEE 802.11 yang memiliki spesifikasi berdasarkan klasifikasi sebagai berikut:

1. Tipe a yang bekerja pada frekuensi $5 \mathrm{GHz}$ dengan bandwidth $20 \mathrm{MHz}$ dan modulasi OFDM (orthogonal frequency division multiplexing) yang memiliki kecepatan maksimum $54 \mathrm{Mbit} / \mathrm{detik}$

2. Tipe $b$ yang bersama tipe a merupakan protokol awal standar 802.11 dengan perbedaan frekuensi $2,4 \mathrm{GHz}$ dan kecepatan maksimum $11 \mathrm{Mbit} /$ detik.

3. Tipe g yang memiliki frekuensi dan bandwidth yang sama dengan tipe $\mathrm{b}$ namun dengan kecepatan maksimum 54 Mbit/detik.

4. Tipe $n$ yang dapat bekerja antara bandwidth 20 atau 40 MHz dan kecepatan sampai $600 \mathrm{Mbit} /$ detik. Tipe a/b/g/n merupakan standar router wifi yang diproduksi sekarang ini.

5. Tipe ac yang merupakan standar yang diajukan pada tahun 2013, dengan keunggulan bandwidth sampai $160 \mathrm{MHz}$ dan kecepatan sampai 3 Gbit/detik.

Pada umumnya jaringan sensor nirkabel bekerja pada standar IEEE 802.15.4 yang dikenal dengan istilah Zigbee [6], yang memiliki keunggulan konsumsi daya yang jauh lebih rendah dari Wifi, dimana router wifi umumnya memerlukan daya $2 \mathrm{~W}$ sampai $20 \mathrm{~W}$ dibanding modul dan antena zigbee yang membutuhkan daya pada satuan miliwatt. Studi ini menggunakan standar Wifi 802.11 dengan alasan pada dunia praktis terutama di Indonesia, penggunaan jaringan Wifi lebih umum digunakan di rumah sakit sehingga selain memperhatikan aspek praktis juga menghemat biaya untuk pengadaan antena dan modul dengan standar Zigbee.

Penulis menggunakan modul wifi ESP8266 yang bekerja dengan standar IEEE 802.11 tipe b/g/n sehingga dapat berkomunikasi dengan router dan antar node pada frekuensi 2,4 $\mathrm{GHz}$ maupun $5 \mathrm{GHz}$.

\section{Komputasi Awan}

Komputasi awan atau cloud computing merupakan sistem jaringan dan penyimpanan data dimana lokasi sebuah jaringan dan data berada pada lokasi yang berbeda. Komputasi awan mengurangi biaya pengadaan sebuah server fisik dengan menggantinya menjadi server remote yang terletak pada lokasi berbeda, dan dapat dikelola oleh pihak berbeda melalui jasa pihak ketiga dengan tingkat keamanan yang bervariasi. Tenaga medis dapat mengambil data pasien dan mengirim secara langsung ke pusat penyimpanan data rumah sakit secara langsung melalui internet. Tenaga medis yang berada di rumah sakit juga dapat mengakses informasi pasien yang berada di rumah dengan memakai sensor nirkabel secara langsung.

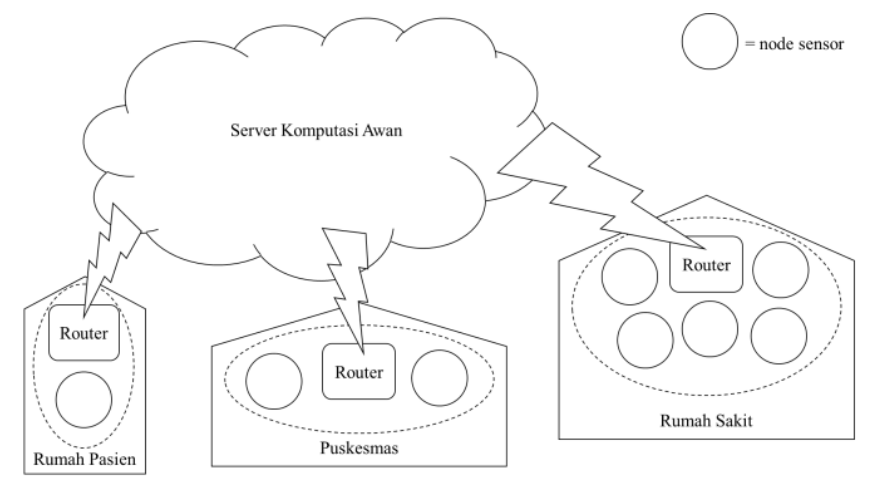

Gambar 2. Topologi jaringan sensor medis berbasis komputasi awan

Komputasi awan memiliki beberapa kekurangan seperti ketergantungan akan akses jaringan internet untuk dapat mengakses data pasien dan membutuhkan tingkat keamanan yang tinggi untuk mencegah data privasi pasien diambil oleh pihak diluar tenaga medis dan pasien. Studi ini mengatasi sistem keamanan yang terbagi menjadi keamanan jaringan pada sensor nirkabel dan layanan komputasi awan itu sendiri.

\section{DESAIN PURWARUPA}

\section{A. Rancangan Node Sensor}

Jaringan sensor yang dirancang pada purwarupa ini terdiri dari sebuah node sensor, sebuah router dan sebuah jaringan awan seperti yang ditunjukkan pada gambar berikut:

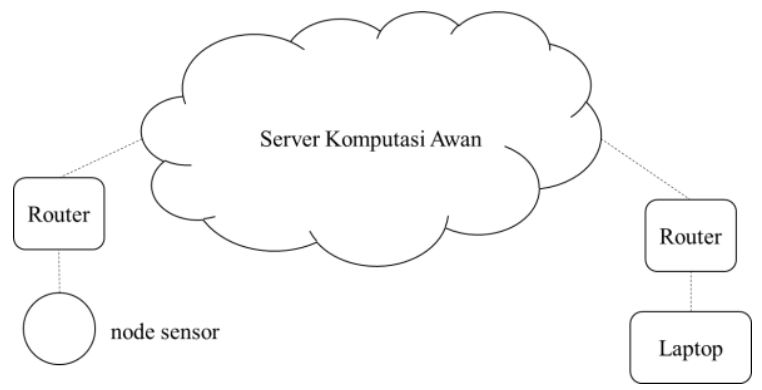

Gambar 3. Jaringan sensor medis nirkabel berbasis komputasi awan

Purwarupa ini terdiri dari sebuah node sensor, sebuah router, dan sebuah server komputasi awan dimana pengukuran sebuah 
node sensor dapat dimonitor pada lokasi dengan memanfaatkan jaringan awan. Alur kerja pengiriman data sensor medis menuju jaringan awan dapat dilihat pada gambar berikut:

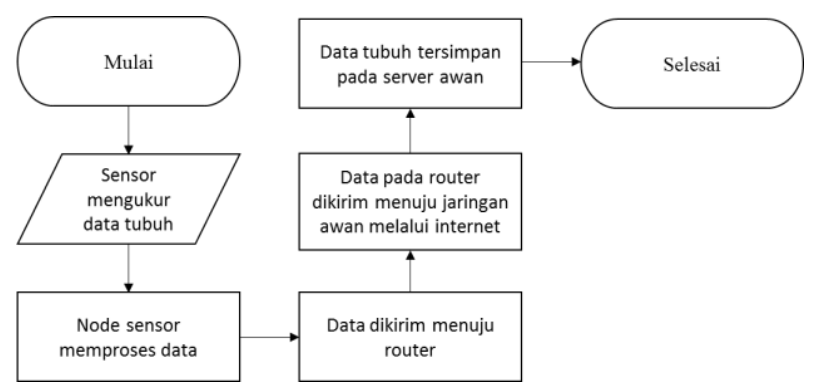

(a)

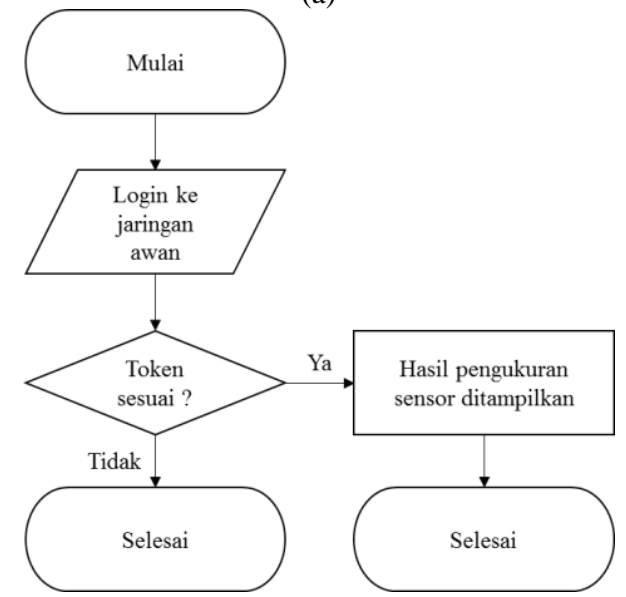

(b)

Gambar 4. Flowchart pengukuran node sensor (a) dan proses monitoring pada jaringan awan (b)

Node sensor yang digunakan terdiri dari beberapa komponen sebagai berikut:

1. NodeMCU sebagai mikrokontroler yang sudah ter-embed dengan modul wifi ESP8266, berfungsi sebagai transceiver, memori dan proses komputasi yang diberi suplai daya $5 \mathrm{~V}$ berupa baterai atau powerbank.

2. SEN11574 sebagai sensor detak jantung.

3. DS18B20 sebagai sensor suhu badan.

Ketiga komponen tersebut dirangkai dengan menggunakan beberapa kabel jumper dan resistor pada breadboard.

Sensor SEN11574 membutuhkan tegangan 3.3-5 V arus 4 $\mathrm{mA}$ dan dilengkapi oleh tiga pin yaitu:

1. Pin positif (+), dihubungkan dengan pin $3,3 \mathrm{~V}$ NodeMCU.

2. Pin negatif (-), dihubungkan dengan ground NodeMCU.

3. Pin input, dihubungkan ke pin GPIO A0 yang akan diprogram di NodeMCU melalui Arduino IDE.

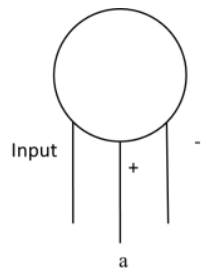

Gambar 5. Rangkaian sensor detak jantung SEN11574
Sensor menerima masukan berupa detak jantung dengan cara menempelkannya pada lengan atau leher, kemudian diproses di NodeMCU dengan kode berikut pada Arduino IDE:

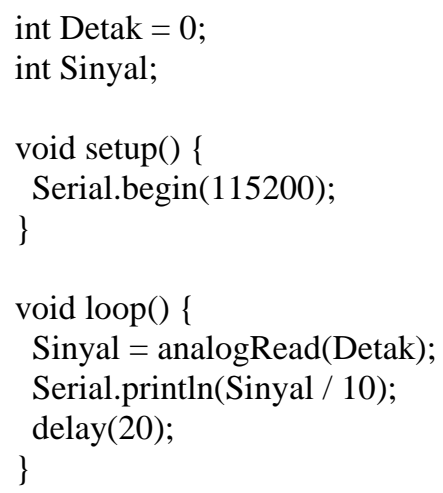

Sensor diberikan dua variabel, dimana variabel pertama diberi nama detak yang merupakan hasil masukan sensor pada pin A0 yang memiliki urutan 0 pada IDE, dan variable sinyal berupa sinyal keluaran sensor. Sensor bekerja pada 115200 baudrate, memiliki delay 20 milidetik atau frekuensi $50 \mathrm{~Hz}$.

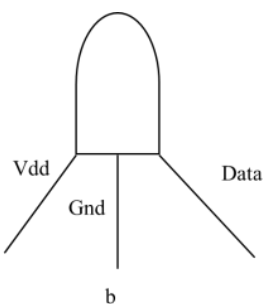

Gambar 6. Rangkaian sensor suhu badan DS18B20

Sensor DS18B20 bekerja pada tegangan 3.3 -5 V arus 1.5 $\mathrm{mA}$ dan terdiri dari tiga pin sebagai berikut:

1. Pin Vdd, dihubungkan dengan pin 3,3 V NodeMCU.

2. Pin gnd, dihubungkan dengan ground NodeMCU.

3. Pin data, dihubungkan dengan pin GPIO NodeMCU.

Sensor bekerja dengan cara digenggam pada telapak tangan atau diapit pada siku lengan atau ketiak. Sensor menerima masukan suhu badan dan mengirimnya ke NodeMCU dengan kode berikut pada Arduino IDE:

\#include <OneWire.h>

\#include <DallasTemperature.h>

\#define Suhu 0

OneWire(Suhu);

void setup(void) \{

Serial.begin(115200);

sensors.begin();

\}

void loop(void) \{

sensors.requestTemperatures();

Serial.println(sensors.getTempCByIndex(0)); delay(20);

\}

Sensor DS18B20 bekerja secara otomatis dengan library DallasTemperature dan OneWire yang merupakan library 
resmi dari perusahaan pembuat sensor, sehingga penulis hanya memasukkan variabel masukan suhu yang diberi nama suhu dan diberi nilai 0 sebagai masukan pin D0 pada NodeMCU. Perbedaan pin A0 dan D0 adalah pada sensor detak jantung menggunakan masukan analog sedangkan sensor suhu badan memakai masukan digital. Sensor bekerja pada baudrate yang sama dengan sensor lain yaitu 115200 dan delay 20 detik agar keluaran sinyal suhu badan sinkron dengan sinyal detak jantung.

NodeMCU beserta kedua sensor dirangkai berdasarkan skema dibawah ini:

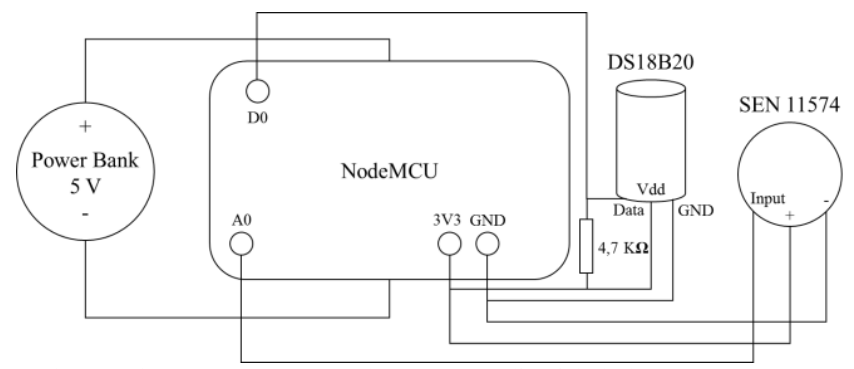

Gambar 7. Skema purwarupa node sensor medis nirkabel

Node sensor memiliki ukuran $8 \mathrm{~cm}$ x $10 \mathrm{~cm}$ dengan ketinggian $3 \mathrm{~cm}$ apabila sensor diletakkan diatas power bank. Node sensor dapat bekerja secara nirkabel apabila berada ada jangkauan sinyal router yang akan dihitung pada sub bab selanjutnnya. Daya hidup node sensor apabila terus aktif berdasarkan perhitungan teoritis adalah sebagai berikut:

Konsumsi arus (NodeMCU + sensor detak jantung + sensor suhu badan $)=(18 \mathrm{~mA}+4 \mathrm{~mA}+1,5 \mathrm{~mA})=23,5 \mathrm{~mA}$. Kapasitas power bank yang digunakan adalah $6600 \mathrm{mAh}$. Sehingga umur hidup node sensor sebelum diisi ulang adalah 6600/23.5 $=280$ jam atau 11-12 hari.

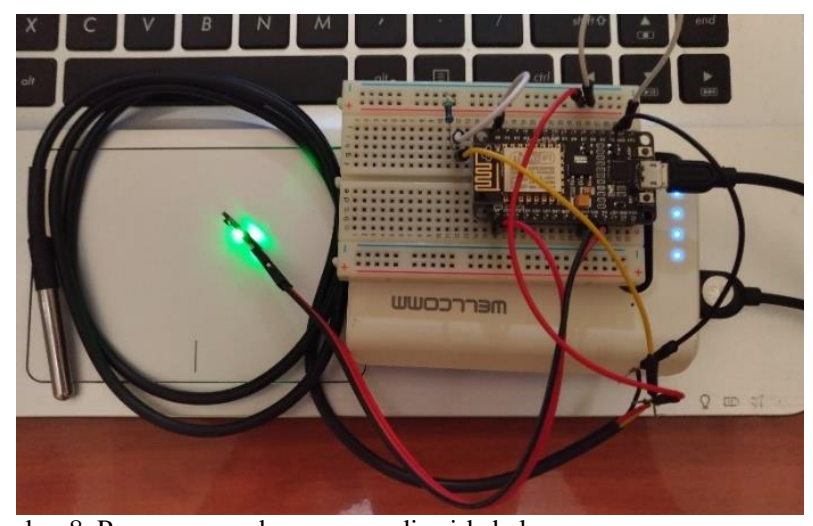

Gambar 8. Purwarupa node sensor medis nirkabel

\section{B. Rancangan Jaringan Komputasi Awan}

Router yang digunakan adalah router sekaligus extender Netgear AC750 dengan spesifikasi sebagai berikut:

Tabel 1

Spesifikasi Netgear AC750

\begin{tabular}{ll}
\hline Parameter & Nilai \\
\hline Standar tipe wifi & a/b/g/n/ac hingga 750 Mbps \\
Frekuensi & 2,4 dan 5 GHz \\
Sekuriti & WPA/WPA2-PSK dan WEP \\
Dimensi & 55,17 x 66,17 x 39 mm \\
Antena Eksternal & 2 \\
\hline \hline
\end{tabular}

Netgear AC750 diatur sedemikian rupa sebagai access point tersendiri dan melalui Arduino IDE dilakukan tambahan baris pengkodean pada NodeMCU agar node sensor dapat otomatis tersambung apabila berada pada jangkauan router AC750. Kode pada IDE yang dimaksud adalah sebagai berikut:

\#define WIFISSID "AC750"

\#define PASSWORD "2213100132"

void setup ()\{

Serial.begin(115200);

client.wifiConnection(WIFISSID, PASSWORD); \}

Dimana diberi tambahan dua variabel sebagai SSID dan password router. Pada purwarupa ini penulis menggunakan jasa situs ubidots.com yang merupakan penyedia jaringan server awan yang terdiri dari layanan penyimpanan data dan monitoring sensor. Masalah keamanan data hasil sensor pasien dapat teratasi dengan sistem sekuriti ubidots yang menyediakan API Key serta token yang masing-masing dapat digunakan saat memprogram NodeMCU pada Arduino IDE. Setiap sensor yang diprogram memasukkan data token yang kemudian diverifikasi oleh pihak ubidots, sehingga hanya pengguna yang memiliki token yang sama dengan sensor yang dapat mengakses dan memonitoring data sensor pasien. Berikut ini masukan kode pada IDE tambahan untuk sambungan ke jaringan awan ubidots.com:

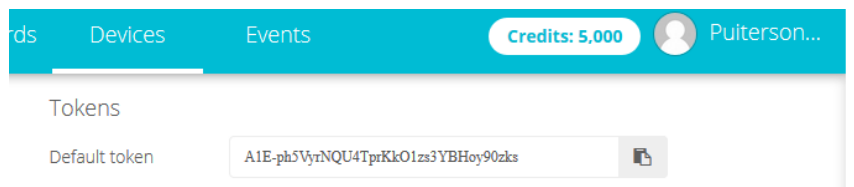

Gambar 9. Sistem sekuriti Ubidots berupa Token

\#include "UbidotsMicroESP8266.h"

\#define TOKEN "A1E-ph5VyrNQU4TprKkO1zs3YBHoy90zks" void loop()\{

float value $=\operatorname{analogRead}(\mathrm{A} 0) / 10$;

float value 2 = digitalRead (D0);

client.add("Detak Jantung", value);

client.add("Suhu Badan", value2);

client.sendAll(true);

\}

Pada IDE diberi baris tambahan untuk memasukkan library UbidotsMicroESP8266 yang merupakan library untuk melakukan hubungan antara modul wifi ESP8266 yang tersedia pada NodeMCU dengan jaringan ubidots. Variabel baru ditambahkan sebagai token yang diisi sesuai dengan token pengguna jaringan. Kemudian pada eksekusi program ditambahkan variabel pengukuran untuk ubidots yang diberi nama Detak Jantung dan Suhu Badan yang akan menampilkan masukan sensor masing-masing dan memberi keluaran pada situs ubidots untuk dimonitoring secara real-time. 


\section{PENGUJIAN DAN ANALISA}

\section{A. Pengujian dan Analisa Node Sensor}

Pengukuran detak jantung dilakukan dengan menempelkan sensor pada pergelangan tangan seperti pada gambar berikut ini

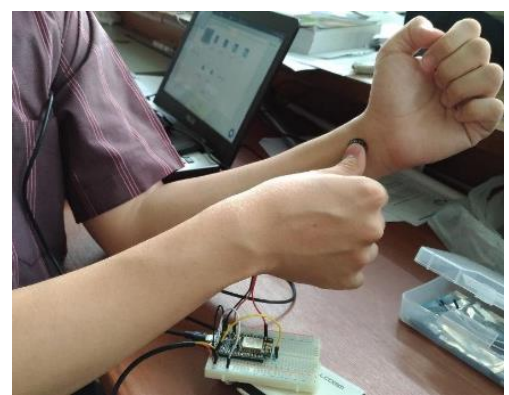

Gambar 10. Metode pengukuran detak jantung dan suhu badan dengan node sensor

Sensor SEN11574 terhubung dengan NodeMCU pada periode pengukuran 20 milidetik atau $50 \mathrm{~Hz}$. Berikut hasil pengukuran yang dikeluarkan oleh tampilan serial plotter Arduino IDE:

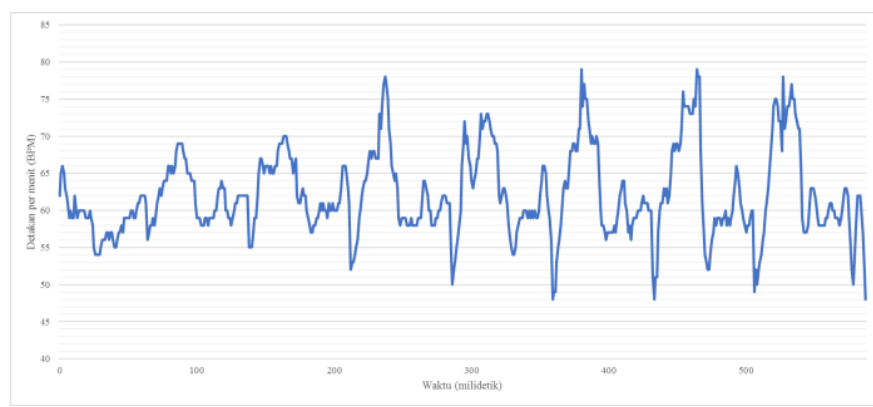

Gambar 11. Hasil pengukuran sensor detak jantung

Grafik tersebut terdiri dari sumbu x yang menampilkan waktu pengukuran dalam satuan milidetik dan sumbu y yang merupakan satuan detak jantung. Pembacaan dilakukan dengan melihat puncak tertinggi sebuah siklus sinyal, dimana berdasarkan grafik diperoleh nilai detak jantung yang terukur berkisar pada 70-80 bpm (beat per minute atau detakan per menit).

Pengukuran suhu badan dilakukan dengan mengapitkan sensor pada lipatan siku lengan, dimana sensor DS18B20 terhubung langsung dengan NodeMCU. Berikut hasil keluaran serial plotter sensor pada NodeMCU:

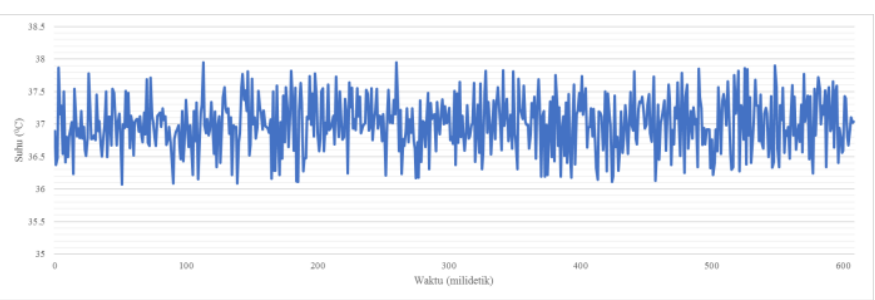

Gambar 12. Hasil pengukuran sensor suhu badan

Sama seperti sensor detak jantung, sumbu x menampilkan waktu pengukuran dalam milidetik dan sumbu y merupakan nilai suhu badan yang diukur oleh sensor. Pembacaan dilakukan dengan melihat nilai rata-rata pengukuran sensor, dimana pada grafik tersebut nilai suhu badan yang terukur berkisar antara 36 - $38{ }^{\circ} \mathrm{C}$ dimana rata-rata pengukuran berada pada suhu $37{ }^{\circ} \mathrm{C}$.

Berdasarkan kedua grafik pada Gambar 9 dan Gambar 10 dapat disimpulkan bahwa node sensor ini dapat bekerja dengan baik dan dapat dianalisa secara tersendiri meskipun tidak terhubung dengan jaringan nirkabel. Pada sub bab berikutnya akan dilakukan pengukuran dan analisa apabila node sensor sudah terhubung dengan jaringan awan secara nirkabel.

\section{B. Pengujian dan Analisa Jaringan Awan}

Pengujian koneksi antara node sensor dengan jaringan awan dilakukan dengan mengirimkan paket data melalui laptop yang terhubung dengan jaringan yang sama dengan node sensor, yang dapat diilustrasikan pada gambar berikut ini:

Paket data dikirim dan diterima balasan

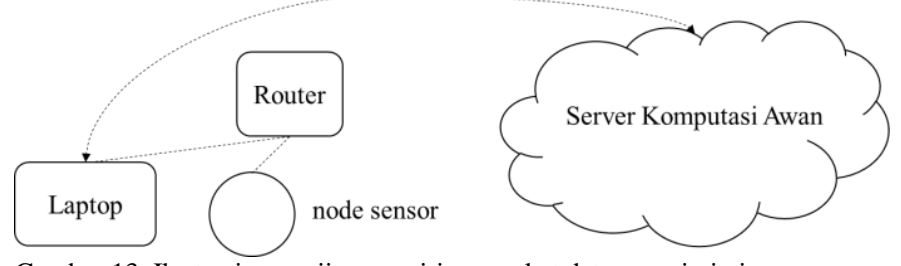

Gambar 13. Ilustrasi pengujian pengiriman paket data menuju jaringan awan

Hasil yang ditampilkan pada command prompt saat melakukan pengiriman paket data sebesar 32 bytes menuju jaringan ubidots, ditunjukkan oleh gambar berikut:

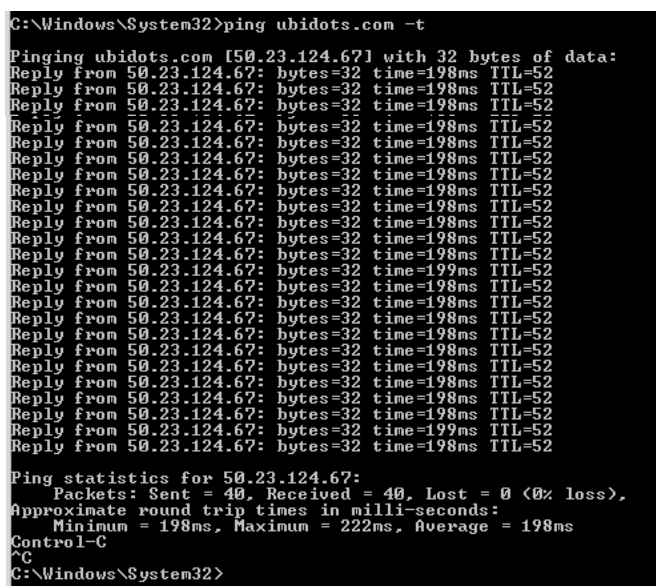

Gambar 14. Pengujian paket data dari jaringan sensor menuju jaringan awan

Paket data yang dikirim diterima dalam waktu rata-rata $198 \mathrm{~ms}$, sehingga membuktikan bahwa jaringan node sensor dapat mengirim data dari pengukuran sensor menuju jaringan awan.

Hasil pengukuran detak jantung dan suhu badan dikirim oleh node sensor menuju router, kemudian melalui internet dikirim menuju jaringan awan, dimana pada jaringan awan dapat dilakukan proses monitoring apabila dilakukan oleh akun dengan token yang sama dengan node sensor. Hasil monitoring pada jaringan awan dapat dilihat pada grafik berikut: 


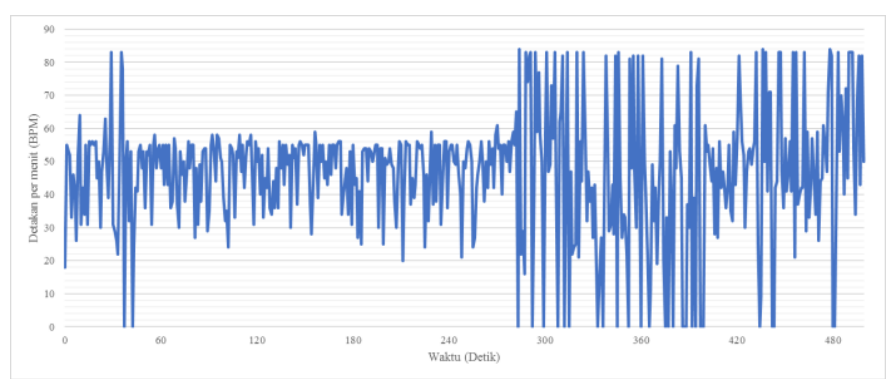

(a)

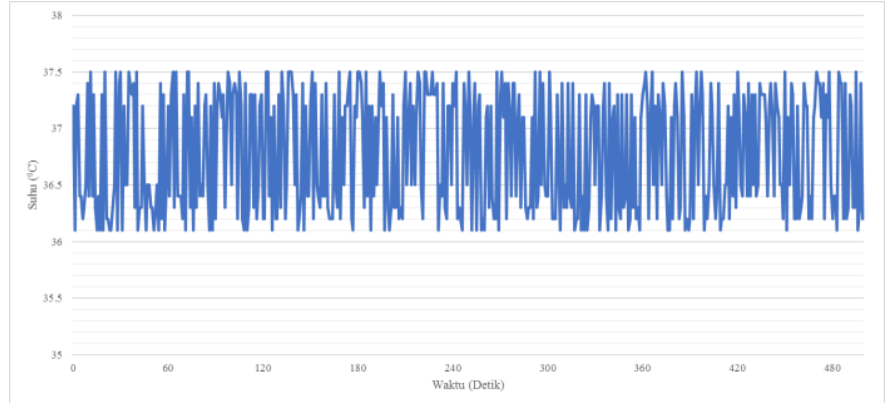

(b)

Gambar 16. Hasil pengujian node sensor pada jaringan awan untuk sensor detak jantung (a) dan suhu badan (b)

Proses pengujian dilakukan selama 480 detik dan terdapat delay sebelum hasil sensor dikeluarkan oleh halaman ubidots pada saat dilakuan pengukuran, sehingga dapat disimpulkan proses monitoring melalui jaringan awan tidak sepenuhnya real-time karena terdapat delay antara pengukuran dan hasil yang ditampilkan. Sumbu pengukuran yang ditampilkan terdiri dari sumbu y sebagai nilai terukur dan sumbu x sebagai waktu.

Beberapa pengujian dilakukan untuk mendapatkan nilai ratarata delay antara waktu pengukuran pada node sensor dan hasil monitoring pada jaringan awan. Pengujian dilakukan dengan melakukan beberapa pengukuran pada node sensor dengan variabel pada saat detak jantung saja, suhu badan saja, dan saat kedua variabel diukur bersamaan. Masing-masing pengukuran dilakukan dengan mencatat waktu saat hasil pertama keluar di server awan pada saat pengukuran. Delay dihitung dengan menggunakan stopwatch, dimana hasil pengukuran delay dapat ditunjukkan pada Tabel 2 berikut:

Tabel 2

Pengukuran delay antara node sensor dan hasil termonitoring pada jaringan awan

\begin{tabular}{lll}
\hline \hline No & Sensor yang Diukur & Delay \\
\hline 1 & Detak jantung & 11,32 detik \\
2 & Detak jantung & 12,04 detik \\
\hline \hline
\end{tabular}

\begin{tabular}{lll}
\hline \hline 3 & Detak jantung & 12,56 detik \\
4 & Suhu badan & 5,04 detik \\
5 & Suhu badan & 4,98 detik \\
6 & Suhu badan & 5,24 detik \\
7 & Kedua sensor & 15,56 detik \\
8 & Kedua sensor & 16,89 detik \\
9 & Kedua sensor & 15,39 detik \\
\hline \hline
\end{tabular}

Berdasarkan Tabel 2 dapat dihitung rata-rata delay saat pengukuran dilakukan dan hasil pengukuran ditampilkan. Untuk sensor detak jantung saja memiliki delay sebesar $(11,32$ $+12,04+12,56) / 3=11,97$ detik, delay untuk sensor suhu badan saja sebesar $(5,04+4,98+5,24) / 3=5,08$ detik, dan delay apabila kedua sensor dilakukan pengukuran bersamaan memiliki delay $(15,56+16,89+15,39) / 3=15,94$ detik. Sehingga dapat disimpulkan bahwa proses monitoring data hasil pengukuran sensor pada jaringan awan tidak bersifat realtime dan terdapat delay sebesar 15,94 detik.

\section{KESIMPULAN}

1. Telah dihasilkan sebuah purwarupa jaringan sensor nirkabel berbasis komputasi awan.

2. Node sensor dapat mengukur dan mengirim data detak jantung dan suhu badan ke jaringan awan apabila terhubung dengan internet.

3. Proses monitoring node sensor dapat dilakukan dengan jaringan awan dengan delay rata-rata 15,94 detik.

4. Purwarupa yang dihasilkan dapat mempermudah proses monitoring kondisi tubuh oleh pihak yang memonitoring pada lokasi yang berbeda.

\section{DAFTAR PUSTAKA}

[1] I. P. A. E. P. and S. Suakanto, "Wireless Sensor Network - Teori \& Praktek Berbasiskan Open Source," Inform. Bandung, 2015.

[2] H. and A. O. Boudra, "An Intelligent Medical Monitoring System Based On Sensors and Wireless Sensor Network," Int. Conf. Adv. Comput. Commun. Informatics, 2014.

[3] J. G. K. and A. Terzis, "Wireless Sensor Networks for Healthcare" Department of Computer Science," johns Hopkins Univ., 2009.

[4] W. D. and C. Poellabauer, Fundamentals of Wireless Sensor Networks. John Wiley \& Sons, Ltd, 2010.

[5] and V. D. S. Kroc, "Personal Wireless Sensor Network for Mobile Health Care Monitoring," 6th Int. Conf. TELSIKS, 2003.

[6] Z. Z. and X. Hu, "ZigBee Based Wireless Sensor Networks and Their Use in Medical and Health Care Domain," Seventh Int. Conf. Sens. Technol., 2013. 